\title{
Histomorphological Assesment of The Effect of Aristolchia Ringens on the Pancreas of Albino Wistar Rats
}

\author{
I. E. Edet, I. U. Umo, K. A. Okon, G. D. Edem, E. O. Inyang
}

\begin{abstract}
The use of Aristolochiaringens in Nigeria and other countries in the world for the treatment of several ailments have been reported but not withoutconsequnces such as nephritis, uroepithelialtumorigenesis, urothelial cancer and liver cancerThis plant has an active compound called aristolochic acid which is a potent carcinogen. In this work, histomorphological assessment of aqueous leaf extract of Aristolochiaringens was studied. Twenty adult male albino wistar rats were used for the study. The animals were divided into four groups of five animals each. Group one was the control group and was given $5 \mathrm{ml}$ of distiled water. Groups $2,3,4$ were the experimental groups, and were given $47.43 \mathrm{mg}, 94.87 \mathrm{mg}$, and $142.30 \mathrm{mg}$ of Aristolochiaringens extract per kilogram body weight respectively for 21 days. On the 22nd day Animals were euthanized using chloroform inhalation. Pancreas were harvested and fixed in $10 \%$ buffered formalin; then processed and stained for histological studies using haematoxylin and eosin stain. Results obtained showed no observable distortion in the histology of the pancreas. Hence, oral administration of aqueous leaf extract of Aristolochiaringens at these dosages for 21 days caused no observable distortion in thecells and tissues of the pancreas.
\end{abstract}

Index Terms - Aristolchiaringens, Aristolochic acid, Histology, Pancreas.

\section{INTRODUCTION}

In recent years, the traditional application of natural compounds of plant origin has been receiving a lot of attention as an alternative source of remedy for the treatment of diseases. This has led to the increase in laboratory (in-vitro) research into herbal medicine to establish their efficacy and their therapeutic applications [1].

Aristolochiaringens is a glabrous bushy climber native of tropical America, introduced to most West African countries as a garden ornamental, and has become naturalized in roadside bush in Sierra Leone, Ghana, Nigeria [2] and DR Congo [3]. In Nigeria, it is mostly found in the north, west, and south - south [4].The plant is commonly called "Dutchman's pipe" and "Snake work" but local names in Nigeria include "UbongEdop" (Ibibio, South-South Nigeria) "Ako-igun" (Yoruba, Southwest Nigeria) and "Dumandutsee" (Hausa, Northern Nigeria).

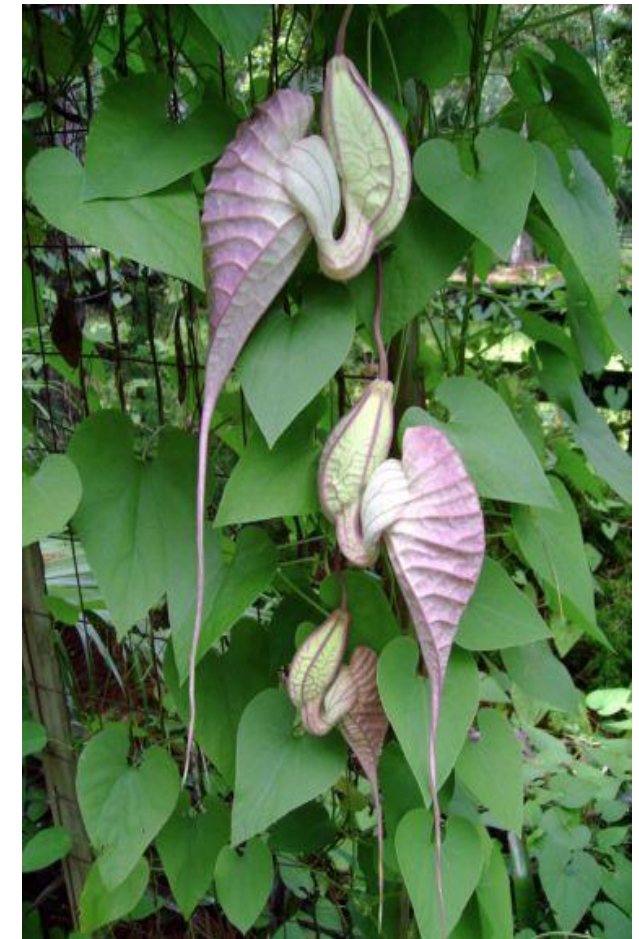

Image showing AristolochiaRingens[5]

Preparations of the leaves, roots, and whole plant have been reported to be used traditionally in Nigeria and other countries for the treatment of diverse ailments. In South America, the plant is used for the treatment of snakebites, fever, ulcers and colon inflammation while the root of the plant is used in Senegal as an antidote for snakebites [6].

[7]Stated that the root of the plant is used in Southwest Nigeria for the treatment of asthma, while [8] reported its use for the treatment of hemorrhoids. The decoction/infusion of the root of the plant is also used as an antidiabetic[9], anti-inflammatory [10] and antitrypanosomal[11]. In Ibibio land (South-South Nigeria), the leaves of the plant alongside with its stock are used by the traditional bone setters for bone setting and anti-inflammatory activities.

The constituents of the plant include the flavonoids, alkaloids tannin and aristolochic acids. The most active constituents of the plant are the aristolochic acids. Aristolochic acids are a family of carcinogenic, mutagenic, and nephrotoxic phytochemicals commonly found in the birthwort (Aristolochiaceae) family of plants [12].

Although this plant has reported benefits, it has also been implicated in Nephritis, urothelial cancer [13], uroepithelialtumorigenesis and liver cancer [14].

The pancreas is a secretory structure with an internal 
hormonal role (endocrine) and an external digestive role (exocrine). In humans, it is located in the abdominal cavity behind the stomach. The endocrine part is composed of hormonal tissue distributed along the pancreas in discrete units called islets of Langerhans; producing several important hormones, including insulin, glucagon, somatostatin, and pancreatic polypeptide, all of which circulate in the blood [15]. Islets of Langerhans have a well-established structure and form density routes through the exocrine tissue. The exocrine part has two main ducts, the main pancreatic duct and the accessory pancreatic duct. These drain enzymes through the ampulla of Vater into the duodenum, pancreatic islet [15].

The role of pancreas in Sugar control and metabolism was a motivation to investigating the consequence of chronic and high dose administration of Aristolochiaringenson the histology of pancreas in adult albino wistar rats.

\section{MATERIALS AND METHOD}

Twenty adult male albino wistar rats weighing between $100 \mathrm{~g}-185 \mathrm{~g}$ were used for this study, these animals were gotten from faculty of Pharmacy University of Uyo and were assigned into four groups of five animals each, group one served as control while groups two, three, and four served as experimental. The animals were housed in a cross ventilated cage and allowed free access to food and water. Good hygiene was maintained by constant cleaning and removal of faeces and spilled food from the cage daily.

Fresh leaves of Aristolochiaringens was gotten from a local farm in Ayadehe in Itu Local Government Area, Akwalbom State, Nigeria. The plant leaves were identified and authenticated by the Department ofBotany and Ecological Science, University of Uyo. Fresh leaves of Aristolochiaringens were macerated and soaked in 800 millimetres of water overnight. The macerated leaves were filtered and the aqueous extract was dried in a water bath, and the dried extract was stored in a refrigerator.

The mean lethal dose, $\left(\mathrm{LD}_{50)}\right.$ of the extract was calculated to establish the dosage of the extract that will elicit expected pharmaceutical effect on the experimental animals without being toxic to the system of the animal.

Calculation of $\mathrm{LD}_{50}=$

$\underline{\text { weight of animals }(\mathrm{g})} \times 1000 \mathrm{mg} / \mathrm{kg}$

$1000 \quad 50 \mathrm{mg} / \mathrm{kg}$

$\mathrm{LD}_{50}=\sqrt{A B}$

$\mathrm{A}=450 \mathrm{mg} / \mathrm{kg}$ (maximum dose that produce $0 \%$ mortality)

$\mathrm{B}=250 \mathrm{mg} / \mathrm{kg}$ (minimum dose that produce $100 \%$ mortality)

$$
\begin{aligned}
& \text { Therefore } \mathrm{LD}_{50}=\sqrt{450 \times 500} \\
& \quad=474.34 \mathrm{mg} / \mathrm{kg}
\end{aligned}
$$

The animals in the four groups were weighed before commencement of administration of extract and weighed again at one week interval till the end of the administration. The aqueous leaf extract of Aristolochiaringens were given to groups two to four in the dose of $47.42 \mathrm{mg} / \mathrm{kg}, 94.87 \mathrm{mg} / \mathrm{kg}$ and $142.30 \mathrm{mg} / \mathrm{kg}$ respectively, according to their body weight for twenty one days. Group one (control group) was given $5 \mathrm{ml}$ of distilled water for 21 days.
On the day 22, animal were euthanize using chloroform inhalation. Pancreas were harvested and fixed in $10 \%$ buffered formalin for seven days; then processed and stained for histological studies using haematoxylin and eosin stain. Tissues were obtained from each group trimmed into $6 \mathrm{~mm}$ and placed in $70 \%$ alcohol overnight. The tissues were subjected to dehydration in two changes of $70 \%, 90 \%, 95 \%$ and absolute alcohol for $45 \mathrm{mins}$ each, cleared in two changes of xylene for 45 minutes each; then embedded in molten paraffin at 60 degree Celsius for infiltration, and allowed to dry for sectioning. Sections were deparaffinised using two xylene washes of two minutes each followed by dehydration; then rinsed twice in 100\%, 95\%, 70\% alcohol for five minutes each and finally rinsed in tap water. The sections were stained in haematoxylin for 10 minutes, washed briefly in running tap water differentiated in $1 \%$ acid alcohol washed in running tap water for fifteen minutes and blued in Scott's water chlorine. Sections were counter stained in eosin for five minutes, washed in tap water, dehydrated in $95 \%$ and absolute alchohol cleared and mounted using DPX.

\section{RESULTS}

Photomicrographs presented in this study were obtained from routine histological stains using hematoxylin and eosin staining at X100 and X400 magnification.

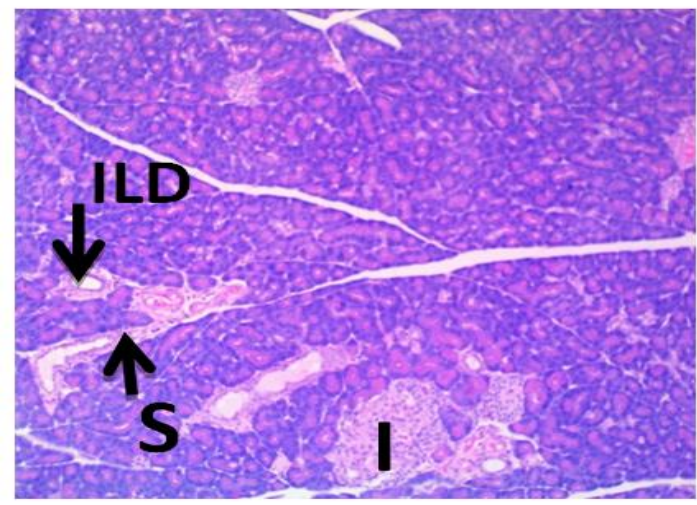

Plate i: photomicrographs of pancreas given distilled water; H\&E. X100. I: islet of Langerhans; ILD: interlobular duct; S: septum.

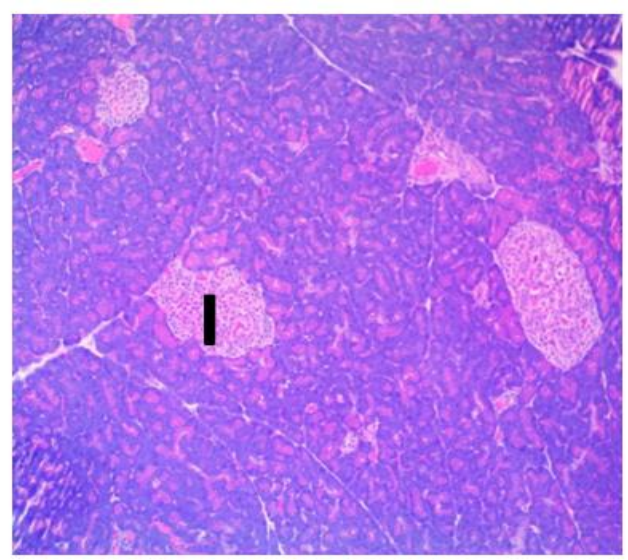

Plate ii: photomicrographs of pancreas treated with 47.43 $\mathrm{mg} / \mathrm{kg}$ of Aristolochiaringens leaf extract; H\&E. X100. I: islet of Langerhans. 


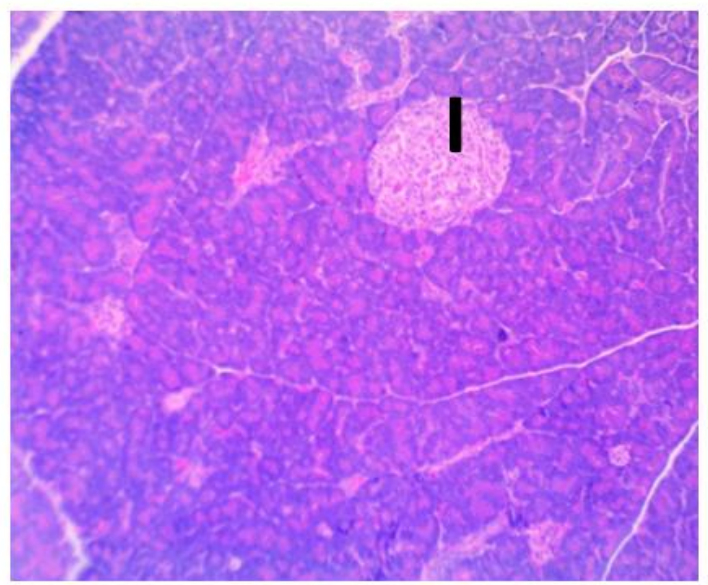

Plate iii: photomicrographs of pancreas treated with 94.87 $\mathrm{mg} / \mathrm{kg}$ of Aristolochiaringens leaf extract; H\&E. X100.I: islet of Langerhans.

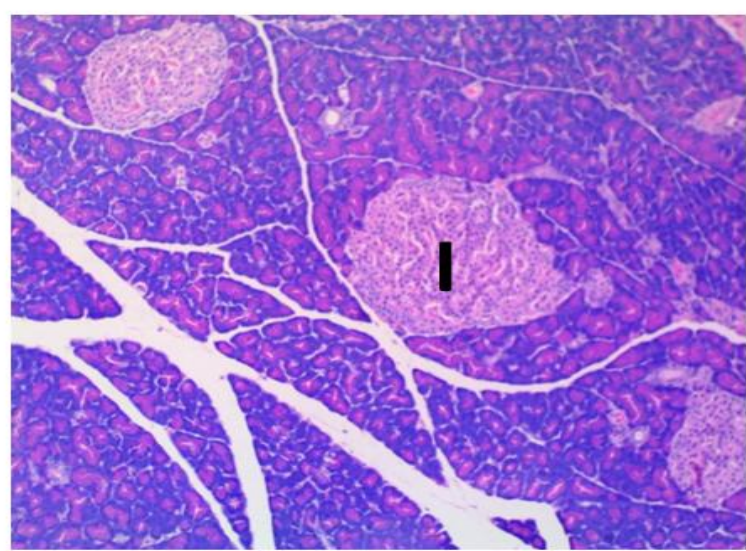

Plate iv: photomicrographs of pancreas treated with 142.30 $\mathrm{mg} / \mathrm{kg}$ of Aristolochiaringens leaf extract; H\&E. X100. I: islet of Langerhans.

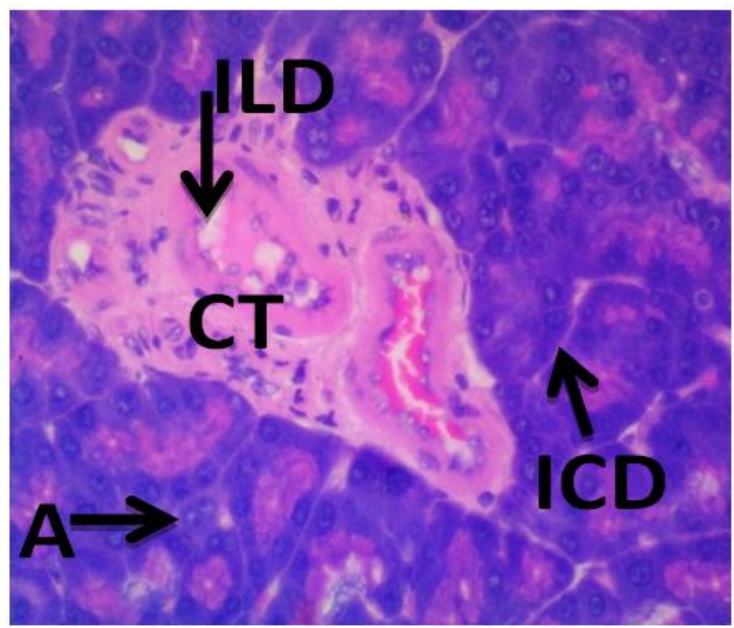

Plate v: photomicrographs of pancreas given distilled water; H\&E. X400A: acini cell; ICD: intercalated duct; ILD: interlobular duct; CT: connective tissue.

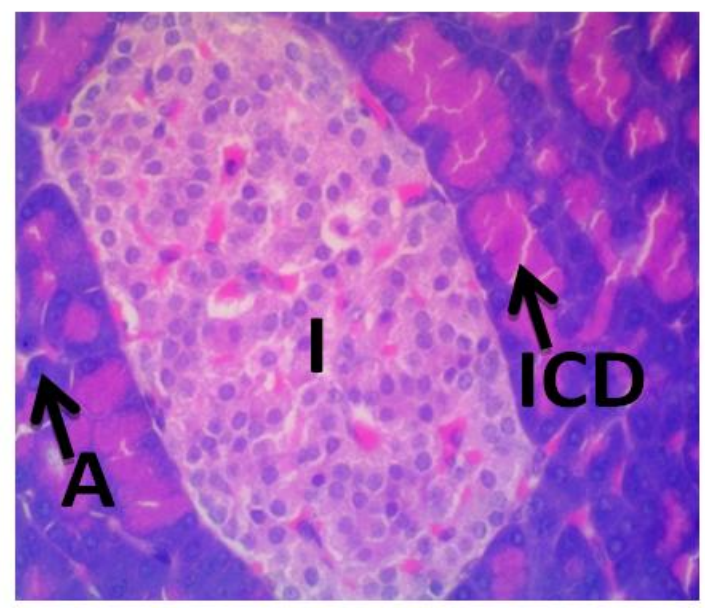

Plate vi: photomicrographs of pancreas treated with 47.43 $\mathrm{mg} / \mathrm{kg}$ of Aristolochiaringens leaf extract; H\&E. X400. I: islet of Langerhans; A: acini cell; ICD: intercalated duct.

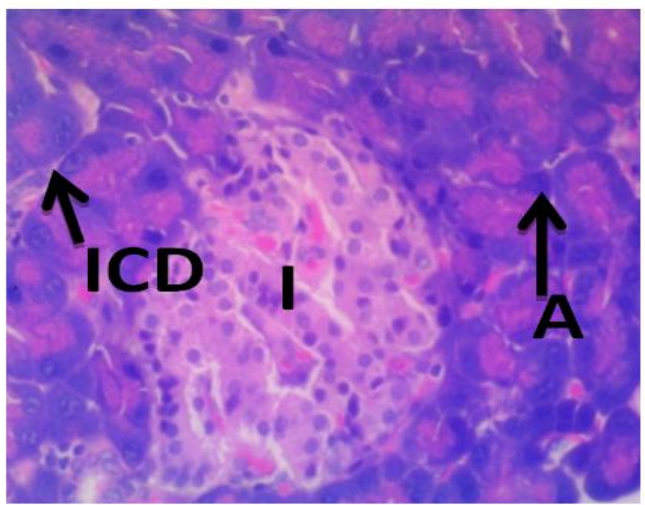

Plate vii: photomicrographs of pancreas treated with 94.87 $\mathrm{mg} / \mathrm{kg}$ of Aristolochiaringens leaf extract; H\&E. X400.I: islet of Langerhans; A: acini cell; ICD: intercalated duct.

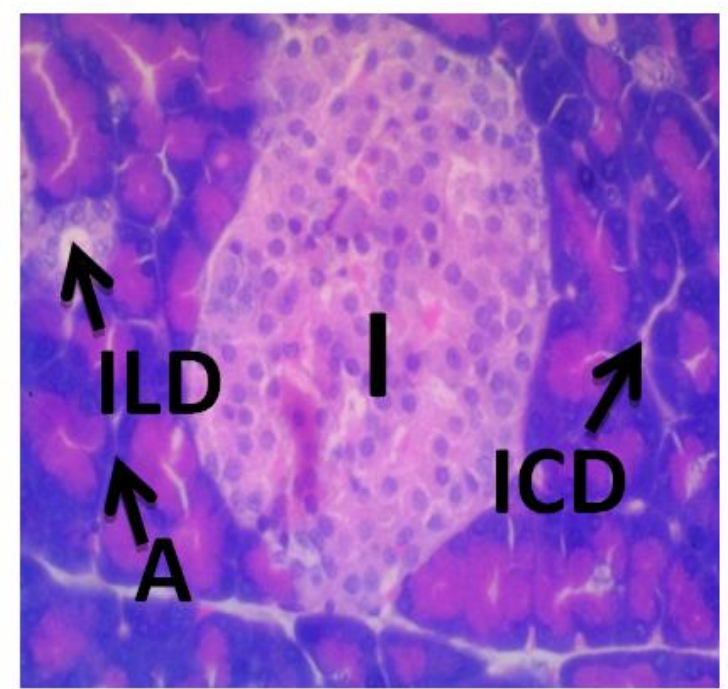

Plate viii: photomicrographs of pancreas treated with $142.30 \mathrm{mg} / \mathrm{kg}$ of Aristolochiaringens leaf extract; H\&E. X400.I: islet of Langerhans; A: acini cell; ICD: intercalated duct; ILD: interlobular duct. 


\section{DISCUSSION}

Histological evaluation on photomicrographs of pancreas of control and treatment group was carried out.

The control group administered with $5 \mathrm{ml}$ of distilled water showed normal cytoarchitecture of the pancreas with normal histological appearance of Islet of Langerhans, acini cells, intercalated duct and interlobular duct.

Resultsfrom treatment groups 2-4, treated with 45.73 $\mathrm{mg} / \mathrm{kg}, 94.87 \mathrm{mg} / \mathrm{kg}, 142.30 \mathrm{mg} / \mathrm{kg}$ respectively were also evaluated. This investigation showed no observable distortion in thecytoarchitecture of the pancreas of treatment groups when compared with the control group. There was no observable difference in the histological appearance of islets of Langerhans, acini cells, intercalated and interlobular ducts seen in treatment groups when compared with the control group. We also observed no difference in histological appearance when treatment groups were compared with each other. This therefore implies that the administration of Aristolochiaringens extract at dosages $47.43 \mathrm{mg} / \mathrm{kg}, 94.87$ $\mathrm{mg} / \mathrm{kg}$ and $142.30 \mathrm{mg} / \mathrm{kg}$ for 21 days caused no observable distortion in the cells and tissues of the pancreas.

\section{CONCLUSION}

Oral administration of $47.43 \mathrm{mg} / \mathrm{kg}, 94.87 \mathrm{mg} / \mathrm{kg}$, and 142.30 $\mathrm{mg} / \mathrm{kg}$ of aqueous leaf extract of Aristolochiaringens for 21 days caused no observable distortion in the cells and tissues of the pancreas.

\section{REFERENCES}

[1]Edeoga, H., Okwu, D and Mbuebie, B (2005) physio-chemical constituents of some Nigerian medicinal plant .Biotechnology journal,4:655-558.

[2]Burkill, H.M, (1985). (The Useful Plants of West Tropical Africa).Vol 1.Royal Botanic Gardens.

[3]DeGroot H., Wanke, S., Neinhuis, C. (2006) Revision of the genus Aristolochia(Aristolochiaceae) in Africa, Madagascar and adjacent islands. 151:219-238.

[4]Randall, R. N,2012.a global compendium of weeds portfolio, Australia, department of agriculture and food, western Australia. Pg 1124

[5] www.google.image.com, aristologiaringens

[6] Neuwinger, H.D, (2000). Medical pharmacy Scientific Publishers, Traditional Medicine.A Dictionary of Plant Use and Application.

[7]Sonibare, M.A., Gbile, Z.O. ( 2008). Ethnobotanical survey of anti-asthmatic plants in South Western Nigeria.Afr J Tradit Complement Altern Med; 5:340-345.

[8] Soladoye, M.O., Adetayo M.O., Chukwuma E.C., Adetunji A.N. ( 2011). Ethnobotanical survey of plants used in the treatment of haemorrhoids in South-Western Nigeria. J AdvDev Res.;2:100-111

[9] Olabanji S.O., Omobuwajo O.R., Ceccato D., Adebajo A.C., Buoso M.C., Moschini G. (2008) Accelerator-based analytical technique in the study of some anti-diabetic medicinal plants of Nigeria.NuclInstrum Methods Phys Res B.;266:2387-2390.

[10] Aigbe F.R., Adeyemi O.O. (2011). The aqueous root extract of Aristolochiaringens (Vahl.) prevents chemically induced inflammation. Plants and Medicine.;77:PF28.

[11] Osho I.B., Lajide L. (2012). Prescreening evaluation of some plant extracts used in ethno-veterinary practices as antitrypanosomal agents. Journal of Medicinal Plants, 6:2056-2060.

[12] Wu,tianshung(2005).chemicalconstituennts and pharmacology of aristolchia species. Studies in natural products chemistry. Pg8633

[13] Wang, J.D., Lai, M.N., Chen, P.C, (2009). "Population-Based Case-Control Study of Chinese Herbal Products Containing Aristolochic Acid and Urinary Tract Cancer Risk".Journal of the National Cancer Institute.102 (3): 179-186.

[14] Ronco Claudio et al., eds. (2008). Critical care nephrology.Elsevier Health Sciences. p. 1699

[15] Paul, A., Ionescu-Tirgoviste, Constantin., Gagniuc., Gubceac.,Elvira.,Mardare,Lilian., Popescu., Irinel., Dima., Simona.,
Militaru., and Manuella (2015). A 3D map of the islet routes throughout the healthy human pancreas". Scientific Reports .5 : 14634. 